\title{
Wybrane problemy upadłości konsumenckiej w świetle nowej regulacji
}

\section{Uwagi wprowadzające}

Dnia 5 grudnia 2008 r. uchwalona została ustawa o zmianie ustawy - Prawo upadłościowe i naprawcze oraz ustawy o kosztach sądowych w sprawach cywilnych ${ }^{1}$, która wprowadziła do prawa upadłościowego i naprawczego ${ }^{2}$ upadłość konsumencką jako nowy typ postępowania oddłużeniowego (art. 4911-49112 PUiN). Przez wyposażenie osób fizycznych nieprowadzących działalności gospodarczej w zdolność upadłościową, zlikwidowano istniejący dotychczas brak równouprawnienia między konsumentami a przedsiębiorcami. Znaczenie tego kroku jest ogromne, przedsiębiorca bowiem ma możliwość rozłożenia ciężaru swego niepowodzenia na osoby trzecie. Niepowodzenie konsumenta ma daleko poważniejsze konsekwencje ${ }^{3}$.

\section{Zakres podmiotowy i przedmiotowy konsumenckiego postępowania upadłościowego}

Zakresem nowej regulacji objęto zasady wspólnego dochodzenia roszczeń wierzycieli od niewypłacalnych dłużników będących osobami fizycznymi nieprowadzącymi działalności gospodarczej, któ-

1 Dz.U. z 2008 r. Nr 234, poz. 1572. Ustawa weszła w życie 31.03.2009 r.

2 Ustawa $z$ dnia 28.02.2003 r. Prawo upadłościowe i naprawcze, Dz.U. z 2003 r. Nr 60, poz. 535 ze zm. (dalej PUiN).

3 Committee on Consumer Credit, 1971, paras 6.1.16(I). 
rych niewypłacalność powstała wskutek wyjątkowych i niezależnych od nich okoliczności (art. 1 ust. 1 pkt 1b PUiN). Do ustawowego sformułowania poczynić trzeba kilka uwag.

Przede wszystkim spostrzec należy, że przepisy prawa upadłościowego i naprawczego nie wprowadzają wymogu posiadania pełnej zdolności do czynności prawnych. W rezultacie więc konsumencką zdolność upadłościową mogą mieć osoby, które w ogóle nie mają zdolności do czynności prawnych (np. osoba fizyczna mająca pełną zdolność do czynności prawnych zaciągnie zobowiązanie, a następnie zostanie ubezwłasnowolniona ${ }^{4}$ ). Co więcej, trafnie zauważono w opinii Biura Analiz Sejmowych ${ }^{5}$, że należałoby zmienić treść art. 8 PUiN, gdyż umożliwia on żądanie ogłoszenia upadłości osobie fizycznej, która była przedsiębiorcą, ale zaprzestała prowadzenia działalności gospodarczej, a od dnia wykreślenia jej z KRS-u lub innego właściwego rejestru nie upłynął rok. Ponadto odstąpiono od charakterystycznego dla upadłości przedsiębiorców oderwania stanu niewypłacalności od przyczyny niewykonywania zobowiązań ${ }^{6}$. W Polsce „wyjątkowość” okoliczności i ich niezależność od dłużnika to warunek sine qua non ogłoszenia upadłości. „Wyjątkowość" powinna być spowodowana obiektywnymi zdarzeniami. Okoliczności zaś niezależne od dłużnika to przede wszystkim przez niego niezawinione ${ }^{7}$. Francuski Code de la consommation przy ocenie zdolności upadłościowej expressis verbis odwołuje się do

4 Problem powstaje również na gruncie zasad rządzących odpowiedzialnością osób fizycznych - wspólników spółek osobowych. Por. R. Adamus, A.J. Witosz, A. Witosz, Upadłość konsumencka. Komentarz praktyczny, LexisNexis, Warszawa 2009, s. 30-33.

5 Opinia do projektu ustawy o zmianie ustawy - Prawo upadłościowe i naprawcze oraz o kosztach sądowych $w$ sprawach cywilnych (druk 831), Biuro Analiz Sejmowych, Warszawa, 21 października 2008 r., s. 2.

6 Por. np. orzeczenie SN z dnia 16.01.1934 r., C I 35/33, Zbiór Orzeczeń 1934, nr 12, poz. 510 „Obojętną jest rzeczą, czy zaprzestanie płacenia długów jest wynikiem "niechęci płacenia", czy źródłem tego jest brak środków".

7 Należy jednak uznać, że w pewnych sytuacjach także brak wiedzy o zaistniałych okolicznościach, do której posiadania nie był on zobowiązany, będzie stanowiła pozytywną przesłankę przyznania zdolności upadłościowej konsumentowi; R. Adamus, A.J. Witosz, A. Witosz, Upadłość, s. 63. 
dobrej wiary dłużnika ${ }^{8}$. Sądy duńskie badają całościową ocenę sytuacji dłużnika, „wiek” długów, ich pochodzenie, sytuację życiową dłużnika w momencie pojawienia się zadłużenia, historię spłat oraz postępowanie dłużnika w okresie oczekiwania na rozstrzygnięcie ${ }^{9}$. W prawie amerykańskim natomiast już od 1841 r. legitymowaną do złożenia wniosku o ogłoszenie upadłości była po prostu każda osoba mająca długi (all persons whatsoever owing debts).

Kluczowym pojęciem dla upadłości konsumenckiej jest niewypłacalność. Dłużnik jest niewypłacalny, jeżeli nie wykonuje swoich wymagalnych zobowiązań pieniężnych (art. 11 ust. 1 PUiN). Niewypłacalność ma miejsce już w pierwszym dniu opóźnienia w spłacie drugiego $z$ kolei wymagalnego zobowiązania, niezależnie od wielkości obu zobowiązań i niezależnie od tego, jak duże jest opóźnienie lub zwłoka w zapłacie ${ }^{10}$. Indyferentna jest natura prawna zobowiązań (lege non distinguente). Mogą być nimi zobowiązania pieniężne i niepieniężne, prywatno- i publicznoprawne. $Z$ punktu widzenia komentowanego przepisu nie ma znaczenia niewykonywanie zobowiązań przedawnionych albo innych zobowiązań naturalnych ${ }^{11}$.

Sąd Najwyższy w odniesieniu do przedsiębiorców expressis verbis przesądził, że ogłoszenie upadłości może nastąpić tylko wówczas, gdy istnieje co najmniej dwóch wierzycieli podmiotu [...], którego dotyczy wniosek ${ }^{12}$. Wymóg wielości zobowiązań realizuje zasadniczy cel upadłości jako egzekucji uniwersalnej. Pozwala równomiernie

\footnotetext{
8 Art. L331-2, L333-2.

9 J. Niemi-Kiesiläinen, I. Ramsay, W.C. Whitford, Consumer Bankruptcy in Global Perspective, Hart Publishing 2003, s. 53.

10 P. Zimmerman, Prawo upadłościowe i naprawcze. Komentarz, Wydawnictwo C.H. Beck, Warszawa 2007, s. 17. W okresie obowiązywania prawa upadłościowego z dnia 24.10.1934 r. (tekst jednolity Dz.U. z 1991 r. Nr 118, poz. 512 ze zm.) niewykonywanie wymagalnych zobowiązań musiało mieć charakter trwały; postanowienie SN z dnia 14.06.2000 r., V CKN $1117 / 00$, LEX nr 56047.

11 A. Witosz (red.), Prawo upadłościowe i naprawcze. Komentarz, Wydawnictwo Prawnicze LexisNexis, Warszawa 2009, s. 45.

12 Uchwała SN z dnia 27.05.1993 r., III CZP 61/93, OSNC 1994, nr 1, poz. 7; postanowienie SN z dnia 5.03.1999 r., I CKN 1121/98, LEX nr 406977.
} 
zaspokoić wszystkich wierzycieli dłużnika ${ }^{13}$, bez względu na to, czy uzyskali tytuły egzekucyjne, czy ich wierzytelności są wymagalne. Mimo to co najmniej $z$ dwóch powodów można mówić o nieadekwatności przyjętego rozwiązania do upadłości konsumenckiej. Po pierwsze, jest to oderwanie pojęcia niewypłacalności od wartości posiadanego przez dłużnika majątku ${ }^{14}$. Po wtóre, chodzi o wymóg wielości długów ${ }^{15}$. W konsekwencji może zaistnieć sytuacja, w której osoba niewypłacalna nie będzie mogła skorzystać z procedury oddłużeniowej tylko dlatego, że zaciągnęła jeden dług. Natomiast dłużnik, który posiada wystarczające środki na spłatę zadłużenia, ale zaprzestał wykonywania wymagalnych zobowiązań, skorzysta z niej. W związku z powyższym, postuluje się zawężenie, dla potrzeb upadłości konsumenckiej, zakresu pojęcia niewypłacalności do sytuacji, w której majątek dłużnika nie wystarcza na pokrycie zaciągniętego zobowiązania. De lege ferenda przeredagować należy także przepis w ten sposób, aby z ustawy mogli skorzystać konsumenci, którzy zaciągnęli wyłącznie jeden dług ${ }^{16}$. Trafnie zauważa się, że jeżeli procedury upadłościowe pozwalają na zrealizowanie zamierzonych celów w stopniu wyższym niż inne sposoby, należy dopuścić możliwość dochodzenia nawet jednej wierzytelności przez jedynego wierzyciela w drodze egzekucji generalnej ${ }^{17}$.

13 Postanowienie SN $z$ dnia 31.01.2002 r. IV CKN 659/00, LEX nr 53150.

14 Por. art. L. 330-1 zd. 1 Code de la consommation.

15 Por. postanowienie SN z dnia 19.12.2002 r. V CKN 342/01, LEX nr 75360 - „dysponujący sporym majątkiem dłużnik będzie uznany za upadłego, jeżeli zaprzestał w sposób trwały płacenia długów”.

16 Opinia do projektu ustawy o zmianie ustawy, s. 3-4.

17 S.A. Muro, Deciding on an Efficient Intomuntary Bankruptcy Filing Petition Rule, Cornell Law School LL.M. Papers Series 2005, nr 6, s. $85-88$. 


\section{Upadłość konsumencka a kodeks cywilny}

Ratio legis umieszczenia upadłości konsumenckiej w ramach prawa upadłościowego tkwi w poszanowaniu klasycznych mechanizmów prawa cywilnego - przede wszystkim autonomii woli i swobody kontraktowania ${ }^{18}$.

Kodeks cywilny zna instytucję zwolnienia z długu (art. 508), która - analogicznie do upadłości konsumenckiej - może doprowadzić do wygaśnięcia zobowiązań. Zwolnienie $z$ długu jest umową i od woli stron zależy ukształtowanie jej treści - np. strony mogą przesądzić o zwolnieniu $z$ części długu ${ }^{19}$, $z$ długu jeszcze niewymagalnego, długu naturalnego ${ }^{20}$. Z kolei w upadłości konsumenckiej dostrzega się element publicznoprawny. Uwolnienie od niespłaconych długów stanowi wyraz określonej aksjologii ustawodawcy ingerującego w konsekwencje prawne niewykonania stosunków obligacyjnych $^{21}$. Stanowi swoistą ochronę ex post przed negatywnymi konsekwencjami własnych autonomicznych decyzji ${ }^{22}$. W imię redukcji zadłużenia społeczeństwa zezwala się na odstąpienie od zasady pacta sunt servanda oraz sprzężonej z nią odpowiedzialności kontraktowej na wypadek, jeśli dłużnik uchylałby się od spełnienia świadczenia lub świadczył niezgodnie $z$ treścią zobowiązania. Upadłość zatem jawi się jako mechanizm ochrony dłużnika ${ }^{23}$.

18 H. Prütting, Restschuldbefreiung, ZIP 1992, s. 883 (cyt. za P. Tereszkiewicz, Zwolnienie z długów, s. 230).

19 Tak K. Zagrobelny, [w:] Kodeks cywilny. Komentarz, E. Gniewek (red.), C.H. Beck, Warszawa 2008, s. 914-915.

20 P. Drapała, Zwolnienie z długu (art. 508 KC), Przegląd Sądowy 2002, nr 7-8, s. 115.

21 P. Tereszkiewicz, Zwolnienie z długów, s. 247.

22 Por. M. Wiggins, Conservative Economics and Optimal Consumer Bankruptcy Policy, Theoretical Inqueries in Law, tom 7, nr 2, lipiec 2006, s. 348-363.

23 I. Ramsay, Models of consumer bankruptcy: implications for research and policy, Journal of Consumer Policy 1997, nr 20, s. 269; w oparciu o kryterium funkcjonalne autor wyróżnia trzy modelowe oblicza upadłości konsumenckiej: upadłość jako odpowiedź na przestępcze postępowanie dłużnika, sposób jego ochrony bądź upadłość jako immanentny składnik państwa dobrobytu. 


\section{Konsumenckie postępowanie upadłościowe}

Konsumenckie postępowanie upadłościowe w Polsce, podobnie jak w Republice Czeskiej, Finlandii czy Szwecji, jest procedurą sądową. We Francji i Luksemburgu toczy się przed organami administracyjnymi. W Holandii natomiast atrakcyjność pozasądowych układów $z$ wierzycielami wspierana jest przez kredyty udzielane przez Volkskredietbank, których wartość nie przekracza kwoty 4000 euro, a oprocentowanie jest niższe od rynkowej stopy procentowej $^{24}$.

W Polsce postępowanie upadłościowe przebiega dwuetapowo. W pierwszej kolejności przeprowadza się likwidację majątku dłużnika. Następnie sporządzany jest plan spłaty wierzycieli, którzy nie zostali zaspokojeni z masy upadłości powstałej po likwidacji majątku upadłego. W zakresie nieuregulowanym przepisami tytułu V w części trzeciej prawa upadłościowego i naprawczego, które odnoszą się do postępowania upadłościowego wobec osób fizycznych nieprowadzących działalności gospodarczej, odpowiednio stosować należy przepisy o postępowaniu upadłościowym obejmującym likwidację majątku (art. 4912 § 1 PUiN). Wyłączeniu podlegają tylko te artykuły, „których stosowanie [...] w sprawach konsumenckich byłoby nieodpowiednie"25. Słusznie zauważono już na etapie opiniowania rządowego projektu (uwagi nie straciły na aktualności), że doszło do wymieszania elementów procedury likwidacyjnej oraz układowej. Najpierw dochodzi do sprzedaży majątku upadłego i jego podziału. Potem, gdy upadły nie dysponuje już żadnym majątkiem, z którego mogliby się zaspokoić wierzyciele, sporządzany jest plan spłat. Plan spłat nakłada na dłużnika obowiązek dalszej spłaty długów, co de

24 Raport Towards a common operational European definition of overindebtedness; Inclusion, Social Policy Aspects of Migration, Streamlikikg of Social Policies Unit, luty 2008, s. 91.

25 Uzasadnienie do rzadowego projektu ustawy, druk 831, s. 3, http:// orka.sejm.gov.pl/Druki6ka.nsf/O/DD4BAC457CFFB574C1257491003FA22E/\$file/831.pdf. 
facto jest wykonywaniem quasi-układu o warunkach narzuconych przez sąd ${ }^{26}$.

W okresie realizacji planu spłaty dłużnik, posiadając ekspektatywę zwolnienia $z$ niespłaconych długów, powinien w należyty sposób wypełniać nałożone nań powinności ${ }^{27}$. Założenie to dobrze oddaje przyjęty w Niemczech termin określający okres realizacji planu - Wohlverhaltensperiode. Tym samym nie przejęto amerykańskiej koncepcji fresh start, umożliwiającej szybkie uwolnienie się od długów, bez konieczności podejmowania trudu spłaty wierzycieli, w zamian za przekazanie wierzycielom wszelkiego mienia niepodlegającego wyłączeniu (Chapter 7 Bankruptcy Code). Nie przekonała polskiego ustawodawcy argumentacja amerykańskiego Sądu Najwyższego, że tylko bezwarunkowo dana druga szansa i „czyste konto na przyszłość, nieskalane uprzednio istniejącymi długami”"28 może istotnie wpłynąć na poprawę sytuacji dłużnika i zmotywować go do pracy. A contrario - w kontynentalnych porządkach prawnych opowiedziano się za tzw. earned start ${ }^{29}$. Uwolnienie się od długów sprzężone jest $z$ obligatoryjnym planem spłaty ${ }^{30}$. Czas realizacji planu jest zróżnicowany - waha się od 3 lat (np. Dania) do 7 (np. w Austrii). Dopiero po upływie tego okresu możliwe jest uwolnienie od zobowiązań. W Austrii conditio sine quo non zwolnienia $z$ długu jest spłata min. 10\% zadłużenia. Jeżeli kwota zaspokojenia wierzycieli będzie niższa niż 10\%, wówczas sąd na wniosek dłużnika może

26 Opinia Krajowej Rady Sądownictwa z dnia 16 maja 2008 r. w przedmiocie rządowego projektu ustawy - Prawo upadłościowe i naprawcze oraz ustawy o kosztach sadowych $w$ sprawach cywilnych, s. 5, http://www.krs. pl/admin/files/100405.pdf.

27 P. Tereszkiewicz, Zwolnienie z długów, s. 246.

28 Local Loan Co. v Hunt 2002 US 234 (1934).

29 U. Reifner, J. Kiesilainen, N. Huls, H. Springeneer, Consumer Overindebtedness and Consumer Law in the European Union, Final Report presented to the Commission of the European Communities, Health and Consumer Protection Directorate-General, wrzesień 2003, s. 166.

30 Por. J. Bigus, E.M. Steiger, When it pays to be honest: How a variable period of good conduct can improve incentives in personal bankruptcy procedings, European Journal of Law and Economics, tom 22, nr 3, s. 233$-253$. 
orzec zwolnienie $z$ długów w oparciu o zasady słuszności lub przedłużyć okres spłat o 3 lata. Anglia i Walia natomiast realizują założenia tzw. trzeciej drogi ${ }^{31}$. Zwolnienie $z$ długów następuje co do zasady nie później niż rok od momentu wszczęcia sprawy, chyba że zostanie wykazane rażące zawinienie dłużnika. Wówczas procedura trwa nawet 15 lat.

Wniosek o ogłoszenie upadłości może zgłosić tylko dłużnik nie częściej niż raz w dekadzie (art. 4912 § 2 PUiN). Jest to jego uprawnienie, nie zaś obowiązek. Nieprzyznanie legitymacji czynnej wierzycielowi (czy poręczycielowi, który spłacił zobowiązania dłużnika) uzasadnia się tym, że ustawa stanowi swoiste „koło ratunkowe” dla dłużnika i skorzystanie $z$ niego musi zależeć wyłącznie od jego woli. Wniosek podlega stałej opłacie w kwocie 200 zł (art. 75 pkt 5 ustawy o kosztach sądowych w sprawach cywilnych ${ }^{32}$ ). Dla porównania w USA opłata za złożenie wniosku o wszczęcie postępowania w trybie Chapter 7 wynosi 299 dol., Chapter 13 - 274 dol. Za zgodą sądu dopuszczalne jest rozłożenie opłat na raty. We Francji wniosek nie podlega żadnym opłatom, a postępowanie oddłużeniowe jest co do zasady bezpłatne ${ }^{33}$.

Sąd rozpoznaje sprawę bez zwoływania wstępnego zgromadzenia wierzycieli, na posiedzeniu niejawnym, chyba że uzna za konieczne przeprowadzenie rozprawy. Uwzględniając wniosek, sąd wydaje postanowienie o ogłoszeniu upadłości, którego obwieszczenie dokonuje się przez ogłoszenie w budynku sądowym oraz zamieszczenie w co najmniej jednym dzienniku o zasięgu krajowym (art. 4912 PUiN).

Postępowanie egzekucyjne zarówno sądowe, jak i administracyjne wszczęte przeciwko upadłemu konsumentowi przed ogłoszeniem

31 I. Ramsay określa regulację angielską mianem „bankruptcy in transition”, „neo-liberal cuckoo in the european bankruptcy nest”; J. Niemi-Kiesiläinen, I. Ramsay, W.C. Whitford, Consumer Bankruptcy, s. 205.

32 Ustawa z dnia 28.07.2005 r., Dz.U. z 2005 r. Nr 167, poz. 1398 ze $\mathrm{zm}$.

33 K. Michalak, Przesłanki wszczęcia konsumenckiego postępowania niewypłacalnościowego (surendettement personel) i postępowania prowadzacego do uwolnienia $z$ reszty długów (retablissement personel) we Francji, Transformacje Prawa Prywatnego 2008, nr 1, s. 45. 
jego upadłości ulega ex lege zawieszeniu $z$ datą ogłoszenia upadłości (art. 145 PUiN). Po uprawomocnieniu się postanowienia o ogłoszeniu upadłości zostaje ono $\mathrm{z}$ mocy prawa umorzone. Inaczej jest we Francji, gdzie dłużnik musi osobiście wnioskować do sądu o wstrzymanie egzekucji wierzytelności cywilnoprawnych oraz do organów podatkowych dla należności podatkowych. W Austrii natomiast wstrzymanie nie odnosi się do długów zabezpieczonych.

Sąd oddala wniosek o ogłoszenie upadłości, jeżeli niewypłacalność dłużnika nie powstała wskutek wyjątkowych i niezależnych od niego okoliczności, w szczególności w przypadku, gdy dłużnik zaciągnął zobowiązanie, będąc już niewypłacalnym (wykładnia literalna prowadzi do wniosku, że nawet zaciągnięcie kredytu konsolidacyjnego na spłatę zadłużenia może być przesłanką negatywną ogłoszenia upadłości), albo do rozwiązania stosunku pracy dłużnika doszło z przyczyn leżących po stronie pracownika lub za jego zgodą. Drugą grupą przyczyn oddalenia wniosku przez sąd jest zaistnienie w okresie dziesięciu lat przed złożeniem wniosku taksatywnie wymienionych okoliczności. Należy do nich prowadzenie postępowania upadłościowego lub innego postępowania, w którym umorzono całość lub część jego zobowiązań, albo w którym zawarto układ czy też nie zaspokojono wszystkich wierzycieli, a dłużnik po zakończeniu lub umorzeniu postępowania zobowiązań swych nie wykonał. Taką przesłanką jest także prowadzenie postępowania upadłościowego przez osobę fizyczną nieprowadzącą działalności gospodarczej, jeżeli postępowanie to zostało umorzone $\mathrm{z}$ innych przyczyn niż na wniosek wszystkich wierzycieli oraz prawomocne uznanie danej czynności prawnej dłużnika za dokonaną z pokrzywdzeniem wierzycieli. Wątpliwości pojawiają się co do tego, czy $\mathrm{w}$ art. 4913 PUiN mamy do czynienia $\mathrm{z}$ numerus clausus przyczyn oddalenia wniosku. W obliczu postrzegania przesłanek ogłoszenia upadłości konsumenta przez pryzmat generalnej klauzuli „wyjątkowych i niezależnych okoliczności” zastanawia nieuwzględnienie w zamkniętym, jak się wydaje, katalogu np. przesłanki popełnienia przestępstwa na szkodę wierzycieli.

W pewnych sytuacjach uzasadnione byłoby ograniczenie postępowania do ustalenia planu spłaty wierzycieli, którego realizacja pozwoli na podjęcie decyzji o oddłużeniu. W przeciwnym razie uza- 
sadniony będzie zarzut niekonstytucyjności ustawy, oparty na nierównym traktowaniu i dyskryminacji ${ }^{34}$. Remedium stanowić mogłoby np. recypowanie rozwiązania francuskiego, w którym obok konsumenckiego postępowania niewypłacalnościowego wykształciło się odrębne postępowanie, prowadzące do uwolnienia $\mathrm{z}$ reszty długów. W przypadkach kwalifikowanych jako „niemożność sanacji” (przy uwzględnieniu m.in. ciężaru długów i niewystarczających środków do ich spłaty, wieku, możliwości zarobkowych, wykształcenia) komisja do spraw niewypłacalności przedstawia wniosek dłużnika sędziemu komisarzowi celem wszczęcia przez niego postępowania prowadzącego do uwolnienia osoby fizycznej z reszty długów ${ }^{35}$. Także w Wielkiej Brytanii od dawna postuluje się zreformowanie jednej $\mathrm{z}$ alternatywnych do upadłości metody oddłużenia, a mianowicie instytucji sądowego ustanowienia zarządu, i uregulowanie kwestii tzw. can't pay debtors przez wprowadzenie procedury NINA (No Income No Asset Debt Relief scheme).

$Z$ dniem ogłoszenia upadłości majątek upadłego konsumenta (należący do upadłego w dniu ogłoszenia upadłości i nabyty przez upadłego w toku postępowania upadłościowego) zostaje przekształcony w masę upadłości (art. 61 i 62 PUiN). Zobowiązania pieniężne upadłego stają się wymagalne, mimo iż nie nastąpił jeszcze termin ich płatności. Zobowiązania majątkowe niepieniężne przekształcają się w zobowiązania pieniężne. Ponadto upadły traci na rzecz syndyka legitymację do występowania w sprawach dotyczących masy upadłości. Mimo to nadal jest stroną w znaczeniu materialnoprawnym $^{36}$ i nie traci prawa własności do swego majątku ${ }^{37}$. Warto dodać, że $\mathrm{z}$ dniem ogłoszenia upadłości jednego $\mathrm{z}$ małżonków ex lege między małżonkami powstaje ustrój rozdzielności majątkowej (art. 53 KRO, art. 124 PUiN), a majątek wspólny wchodzi do masy upadło-

34 Por. wyrok 18/2003 belgijskiego Cour d'Arbitrage $z$ dnia 30.01.2003 r., http://www.arbitrage.be/fr/common/home.html.

35 K. Michalak, Przesłanki wszczęcia, s. 33-56.

36 Wyrok NSA z dnia 11.10.2005 r., FSK 2449/04, Palestra 2007, nr 3-4, s. 291.

37 Wyrok NSA z dnia 7.03.2002 r., III SA 1787/00, Biuletyn Skarbowy 2003, nr 3, s. 26. 
ści. Małżonek upadłego nie może żądać wyłączenia $z$ masy upadłości przedmiotów, które by mu przypadły, gdyby dokonano podziału majątku wspólnego. $Z$ tytułu swego udziału w majątku wspólnym może on tylko zgłosić do masy upadłości wierzytelność pieniężną, której wysokość odpowiada wartości jego udziału. W doktrynie mówi się z tego powodu o „swoistym podziale majątku wspólnego"38.

Obowiązkiem dłużnika po ogłoszeniu upadłości jest wskazanie i wydanie całego majątku syndykowi. Syndyk ustala skład masy upadłości przez sporządzenie spisu inwentarza składników znajdujących się w posiadaniu upadłego. Domniemywa się, że rzeczy będące w posiadaniu upadłego w dniu ogłoszenia upadłości należą do jego majątku (art. 69 PUiN).

Sędzia-komisarz może zezwolić, aby likwidację masy upadłości, obejmującą spieniężenie majątku i równe zaspokojenie wierzycieli $\mathrm{w}$ ramach poszczególnych kategorii wierzytelności, przeprowadził sam upadły pod nadzorem syndyka (art. 4912 § 5 PUiN). W Austrii zarząd w postępowaniu konsumenckim sprawuje zasadniczo sam dłużnik, a jedynie określone kategorie czynności są wyjęte spod jego kompetencji (§ $186 \mathrm{KO}$ ).

Jeżeli w skład masy upadłości wchodzi lokal mieszkalny lub dom jednorodzinny, w którym zamieszkuje upadły konsument, z sumy uzyskanej z jego sprzedaży wydziela się kwotę odpowiadającą przeciętnemu czynszowi najmu lokalu mieszkalnego za okres dwunastu miesięcy. Uwzględnia się potrzeby mieszkaniowe upadłego i liczbę osób pozostających z dłużnikiem we wspólnym gospodarstwie domowym. Wydaje się, że należy uwzględnić także fakt np. ewentualnego naturalnego powiększenia się rodziny ${ }^{39}$. Sędzia-komisarz ma kompetencję do przyznania zaliczki na poczet należnej upadłemu kwoty (art. 4916 PUiN). W Danii i Szwecji natomiast do sprzedaży domu dochodzi wyłącznie w sytuacji, gdy wydatki są zbyt

38 M. Uliasz, Nowe Prawo upadłościowe i naprawcze - wpływ ogłoszenia upadłości na stosunki majątkowe małżeńskie upadłego, Monitor Prawniczy 2003, nr 11, s. 488.

39 R. Adamus, A.J. Witosz, A. Witosz, Upadłość, s. 75. 
wysokie i istnieje szansa na ich obniżenie przez zmianę miejsca zamieszkania $^{40}$.

Podczas gdy w Szwecji plany podziału funduszy masy upadłości sporządzane są przez organ państwowy (Kronofogdemynidighet), a we Francji i Luksemburgu przez komisje ds. niewypłacalności, Polska jest wierna zasadzie sporządzania planu przez syndyka. Po sporządzeniu planu sąd na wniosek dłużnika, którym jednak nie jest związany, i po przeprowadzeniu rozprawy wydaje postanowienie o ustaleniu planu spłaty wierzycieli upadłego (art. 4917 PUiN). $\mathrm{Z}$ chwilą uprawomocnienia się postanowienia o ustaleniu planu powołanie syndyka wygasa ex lege (art. 4918 PUiN). Tym samym jego rola w konsumenckim postępowaniu upadłościowym ogranicza się do postępowania likwidacyjnego. Nie obejmuje już etapu spłacania należności niezaspokojonych na podstawie planu podziału. Rozwiązanie takie wychodzi naprzeciw postulatowi ograniczania kosztów postępowania upadłościowego (skoro syndyk nie działa, upadły nie ponosi kosztów jego działalności).

Plan spłaty określa, w jakim zakresie i w jakim czasie (nie dłuższym niż pięć lat) upadły jest obowiązany spłacać należności niezaspokojone na podstawie planu podziału oraz jaka część zobowiązań, po wykonaniu planu, zostanie umorzona (art. 4917 § 1 PUiN). Wykładnia literalna sformułowania ,jaka część zobowiązañ” prowadzi do wniosku, że umorzenie powinno nastąpić proporcjonalnie względem wszystkich wierzycieli. Zwrócić należy także uwagę, iż zakresem planu spłat objęto zobowiązania powstałe do dnia ogłoszenia upadłości, jak również zobowiązania upadłego powstałe do dnia ustalenia planu (art. 4917 § 1 zd. ostatnie PUiN). Tym samym przełamano zasadę przyjętą w upadłości przedsiębiorców (w rozumieniu art. 5 PUiN), że zobowiązania powstałe po dniu ogłoszenia upadłości winny być zaspokajane na bieżąco i co do zasady w całości $^{41}$. Niemniej jednak art. 49112 PUiN statuuje, że umorzeniu nie ulegają zobowiązania powstałe po ogłoszeniu upadłości, co rodzi

40 U. Reifner, J. Kiesilainen, N. Huls, H. Springeneer, Consumer Overindebtedness, s. 188.

41 R. Adamus, A.J. Witosz, A. Witosz, Upadłość, s. 81. 
wyraźną sprzeczność z art. 4917 PUiN, która jak najszybciej winna być usunięta.

W okresie wykonywania planu spłaty upadły nie może dokonywać czynności prawnych przekraczających granice zwykłego zarządu (art. 4919 § 1 PUiN). Wydaje się, że ustawodawca zastosował zbyt rygorystyczne obostrzenia. Zwiększenie się wynagrodzenia za pracę lub dochodów uzyskiwanych $z$ osobiście wykonywanej przez upadłego działalności zarobkowej nie pociąga za sobą zmiany planu spłaty wierzycieli przez podwyższenie kwot przypadających wierzycielom (art. 49110 \& 2 PUiN). Intencją ustawodawcy jest więc zwiększenie aktywności zawodowej dłużników. Skoro tak, to niezrozumiałe są pobudki, dla których ograniczono możliwość dysponowania nimi. Analogicznego rozwiązania nie przyjęto w odniesieniu do upadłego przedsiębiorcy (w rozumieniu art. 5 PUiN), sprawującego zarząd własny, którego niewypłacalność powstała w wyjątkowych i niezależnych od niego okolicznościach. Za zgodą nadzorcy sądowego uprawniony jest on do dokonywania czynności przekraczających zakres zwykłego zarządu (art. 76 ust. 3 PUiN). Zagraniczne porządki prawne niejednolicie unormowały zagadnienie dopuszczalności dysponowania mieniem uzyskanym w czasie dokonywania spłaty. W Danii środki pozyskane po ogłoszeniu upadłości nie mają wpływu na kształt planu. W Niemczech połowa spadku, w Finlandii zaś każdy element majątku o wartości przekraczającej tysiąc euro jest przeznaczany na spłatę wierzycieli ${ }^{42}$. Zastanowić się należy, do jakiego stopnia państwo, w zamian za ekspektatywę oddłużenia, legitymowane jest do przesunięcia dłużnika na granicę minimum egzystencjalnego. Warto zasygnalizować rozwiązanie przyjęte w Szwajcarii, które gwarantuje dłużnikowi godny poziom życia podczas przeprowadzania postępowania oddłużeniowego. Praktyka orzecznicza rozwinęła bardzo liberalną wykładnię pojęcia "godny poziom życia”, odnosząc niezbędne minimum egzystencjalne danego dłużnika do poziomu właściwego dla jego środowiska ${ }^{43}$.

42 Ibidem, s. 192-193.

43 Art. 265 ust. 2 SchKG; K. Amonn, D. Gasser, Grundriss des Schuldbetreibungs-und Konkursrechts, Bern 1997, s. 396. 
$Z$ wyłączeniem zakupów na raty i $z$ odroczonym terminem płatności, upadły może zaciągać zobowiązania, o ile są one niezbędne dla utrzymania swojego i osób, w stosunku do których ciąży na nim obowiązek dostarczania środków utrzymania (taki zapis może sprawić wiele trudności osobom żyjącym w konkubinacie, na których nie ciąży powinność wzajemnej pomocy). Do ustawy nie wprowadzono jednak zapisów o przekazywaniu danych upadłego konsumenta do biura informacji gospodarczej ${ }^{44}$. Oznacza to, że np. bank nie będzie miał sposobności skontrolowania, czy potencjalny klient jest bankrutem. Tym samym otwarta zostaje droga dla licznych nadużyć, które nakręcać będą spiralę zadłużenia. Upadłość konsumencka może więc wywołać efekt domina - bankructwo konsumenta doprowadzi do upadłości wierzyciela. $Z$ drugiej strony, umieszczenie danych w BIG niweczyłoby szansę na nowy start w życiu, prowadziłoby do stygmatyzacji (tzw. Victorian view of bankruptcy), obniżało wiarygodność w kontaktach np. z bankami, pracodawcami ${ }^{45}$. Warto także nadmienić, że żadna europejska ustawa dotycząca upadłości konsumenckiej nie zawiera klauzuli przeciwdziałającej dyskryminacji zrehabilitowanego dłużnika. We Francji zaś przyjęto rozwiązanie następujące: Bank Narodowy prowadzi rejestr osób zadłużonych i niewypłacalnych, który zastrzeżony jest tylko do wiadomości banków. Wpis dokonywany jest na okres ośmiu lat.

Dla ochrony praw wierzycieli, corocznie do kwietnia dłużnik składa sprawozdanie dotyczące wykonania planu spłaty oraz osiągniętych przychodów i nabytych składników majątkowych (art. 4919 § 3 PUiN). Jeżeli upadły konsument $z$ powodu przemijającej przeszkody nie może wywiązać się z obowiązków określonych w planie spłaty, sąd może zmienić plan spłaty wierzycieli w ten sposób, że przedłuży termin spłaty, maksymalnie o 2 lata, lub zmieni wysokość poszczególnych rat (art. 49110 § 1 PUiN). Niedopuszczalne jest zmniejszenie całej płatności. Natomiast gdy w okresie wykony-

44 Taką możliwość w art. 49111 przewidywał projekt PO dostępny na stronie http://www.platformanawiejskiej.pl/ustawy/920.html.

45 Raport Krajowego Rejestru Długów, Upadłość konsumencka a dostęp do kredytu, listopad 2008 r., s. 7-10. 
wania planu sytuacja materialna dłużnika ulegnie znaczącej poprawie (np. odziedziczy spadek), każdy z wierzycieli może wystąpić do sądu $z$ wnioskiem o podwyższenie kwot, jakie im przypadają (art. 49110 § 2 PUiN). W Finlandii precyzyjnie określono, że wzrost dochodów o kwotę przekraczającą 800 euro rodzi obowiązek przekazania wierzycielom rat w wyższej kwocie ${ }^{46}$. Pamiętać jednak należy, że każdorazowa modyfikacja ustalonego przez sąd planu wymaga uprzywilejowania bądź to zasady res iudicata, bądź też względów natury prakseologicznej, zmierzających do zapewnienia ochrony wierzycielom.

W razie niewykonywania przez upadłego obowiązków ustalonych w planie spłaty lub też na skutek niewłaściwego zachowania się (np. zatajenie przychodów, dokonanie czynności prawnej prawomocnie uznanej za dokonaną z pokrzywdzeniem wierzycieli) sąd na wniosek wierzyciela, po przeprowadzeniu rozprawy, uchyla plan spłaty wierzycieli oraz umarza postępowanie upadłościowe (art. 49111 PUiN). Oznacza to, że ewentualne oddłużenie nastąpi nie wcześniej niż za 10 lat.

Po wykonaniu przez upadłego obowiązków określonych w planie spłaty sąd wydaje postanowienie o umorzeniu niezaspokojonych zobowiązań upadłego objętych planem, z wyjątkiem zobowiązań obejmujących świadczenia okresowe, do których tytuł prawny nie wygasł oraz powstałych po ogłoszeniu upadłości, i o zakończeniu postępowania (art. 49112 PUiN). Zasadą przyjętą w polskim prawie upadłościowym jest globalne umorzenie wierzytelności. W tym kontekście zastrzeżenia budzi brak przedmiotowego ograniczenia zwolnienia $z$ długów, które dostosowane byłoby do upadłości konsumenckiej. Obecna regulacja (art. 369 § 3 PUiN) zdaje się zezwalać na umorzenie np. zobowiązań z czynów niedozwolonych czy z niektórych przestępstw, co nie da się pogodzić $z$ aksjologicznym uzasadnieniem ustawy, która promuje uczciwość dłużnika ${ }^{47}$. W prawie niemieckim zwolnienie $z$ długów powoduje przekształcenie się

46 U. Reifner, J. Kiesilainen, N. Huls, H. Springeneer, Consumer Overindebtedness, s. 193.

47 Por. np. art. $369 \S 1$ pkt 3 PUiN. 
niewykonanych zobowiązań w zobowiązania naturalne ${ }^{48}$. W Austrii sądowe orzeczenie o zwolnieniu $z$ niespłaconych $\mathrm{w}$ postępowaniu długów rozciąga się na odsetki od wierzytelności i roszczenia wierzycieli o zwrot kosztów postępowania. Dłużnik zwolniony jest też od roszczeń regresowych przysługujących poręczycielom i współdłużnikom, których odpowiedzialność względem wierzycieli dłużnika nie zmienia się po ogłoszeniu upadłości (§ $214 \mathrm{KO}$ ).

\section{Skutki upadłości konsumenckiej w zakresie prawa podatkowego}

Po stronie konsumenta, który ogłosi upadłość, powstanie obowiązek zapłaty podatku PIT od umorzonej kwoty, która to kwota stanowi przychód dłużnika. Zgodnie $z$ ogólną definicją przychodu, zawartą w art. 11 ust. 1 ustawy o podatku dochodowym od osób fizycznych ${ }^{49}$, przychodami są otrzymane lub pozostawione do dyspozycji podatnika w roku kalendarzowym pieniądze i wartości pieniężne oraz wartość otrzymanych świadczeń w naturze i innych nieodpłatnych świadczeń. Obecna regulacja zawiera co prawda przepisy, które wyłączają z kategorii przychodów wierzytelności umorzone w postępowaniu upadłościowym ${ }^{50}$, jednakże znajdują one zastosowanie wyłącznie do podmiotów prowadzących działalność gospodarczą. Paradoksalnie zatem oddłużenie konsumenta może doprowadzić do wtórnego zadłużenia względem fiskusa. Z kolei wierzyciel będzie miał możliwość zaliczenia niespłaconej i umorzonej części należności do kosztów podatkowych ${ }^{51}$. Warto zwrócić uwagę w tym kontekście na regulację austriacką (Konkursordnung), która przewiduje wypadek wystąpienia ponownej niewypłacalności konsumenta w trakcie postępowania oddłużeniowego. W takiej sytuacji po raz kolejny wszczyna się postępowanie upadło-

\footnotetext{
48 § 301 ust. 3 InsO.

49 Ustawa z 26.07.1991 r. o podatku dochodowym od osób fizycznych, Dz.U. z 2000 r. Nr 14, poz. 176 ze zm. (dalej uPDOF).

50 Artykuł 14 ust. 3 pkt 6 uPDOF.

51 Artykuł 23 ust. 1 pkt 14, 20 oraz art. 23 ust. 2 uPDOF.
} 
ściowe, które nie ma jednak żadnego wpływu na już trwające postępowanie oddłużeniowe ${ }^{52}$.

Przepisy o upadłości konsumenckiej pozostaną indyferentne wobec rozliczenia VAT przez wierzycieli mimo istnienia tzw. ulgi na złe długi. Ulga na złe długi polega na możliwości dokonania korekty podatku należnego $\mathrm{z}$ tytułu sprzedanych towarów lub usług, gdy podstawą opodatkowania są wierzytelności, których nieściągalność została uprawdopodobniona. Konstytutywną przesłanką skorzystania $z$ ulgi jest jednak to, aby tak dłużnik, jak i wierzyciel był podatnikiem VAT, zarejestrowanym jako podatnik VAT czynny, czyli prowadzący działalność gospodarczą ${ }^{53}$.

\section{Podsumowanie}

Konkludując poczynione uwagi, warto przywołać stwierdzenie F. Borman'a, który powiedział kiedyś, że kapitalizm bez bankructwa jest jak chrześcijaństwo bez piekła ${ }^{54}$. Upadłość konsumencka wydaje się „czyśćcem” dla dłużników, którzy z niezawinionych przez siebie powodów znaleźli się w kłopotach finansowych. Łagodzi ona działania „niewidzialnej ręki rynku”.

Doświadczenia europejskie wskazują na rosnące zainteresowanie instytucją upadłości konsumenckiej. $Z$ danych Creditereform ${ }^{55}$ wynika, że w Niemczech w 1999 r. ogłoszono upadłość 2450 konsumentów; rok później - 10 360, w 2007 - 105300.

Na obecną sytuację Polski składa się m.in. wzrost kwoty zagrożonych kredytów zaciąganych przez osoby prywatne (w III kwartale 2008 r. osiągnęły poziom 10,8 mld zł) i wzrost zadłużenia gospo-

52 P. Tereszkiewicz, Postępowania upadłościowe i oddłużeniowe dla konsumentów $w$ Stanach Zjednoczonych i $w$ niektórych krajach europejskich (cz.1), Transformacje Prawa Prywatnego 2000, nr 1-2, s. 120.

53 M. Majkowska, Bankrut będzie musiał zapłacić podatek od umorzonego długu, Gazeta Prawna z dnia 6.08.2008 r., nr 153, s. 9.

54 Wypowiedź F. Bormana zacytowana w artykule Alexander L. Taylor, The Growing Bankruptcy Brigade, Time Magazine $z$ dnia 18.10.1982 r.

55 Raport Creditreform, Upadłości $w$ Niemczech $w$ I połowie 2008, Warszawa, 8 lipca 2008 r., s. 2. 
darstw domowych (318 mld zł). Ponadto 12,6\% gospodarstw deklaruje problemy $z$ obsługą zobowiązań, $z$ czego $1 / 4$ nie spłaca swoich zobowiązań od ponad pół roku ${ }^{56}$. Zjawiska te, przy jednoczesnym wyhamowaniu gospodarki, potwierdzają celowość podjętej przez ustawodawcę inicjatywy. Zastrzeżenia budzi natomiast skomplikowana procedura, lakoniczność i niejasność generalnego odesłania do przepisów o upadłości przedsiębiorców. Jak dosadnie twierdzą niektórzy, „cała regulacja przypomina ser szwajcarski z zaskakująco dużą ilością dziur i można ją zaliczyć do legislacji typu radosno-towarzyskiego. Radosnej, bo myśl przednia, a wykonanie kabaretowe, a towarzyskiej, bo daje pretekst do licznych spotkań poświęconych niejednoznacznościom i błędom w ustawie"57. Większą wagę nadto należałoby przywiązać do zagadnienia edukacji konsumentów oraz skoncentrować siły na lepszym przystosowaniu społeczeństwa do zmieniających się warunków. Omówienie tych problemów wykracza jednak poza ramy opracowania.

\section{Abstract \\ Some problems of consumer bankruptcy in the light of the new regulations}

On 31 March 2009, a new concept of consumer bankruptcy was introduced in Poland, making it possible for individual debtors who are not engaged in business activities to be declared bankrupt. The paper shows how legislation of Poland has dealt with the protection of the individual's existence in the case of his/her bankruptcy and how, by protecting him/ /her, the state makes it possible for the individual to continue his/her existence in the society and to reconstruct his/her economic potential. The legislators were following legal systems of the European countries and the American model of consumer bankruptcy to take advantage of their expe-

56 Raport Krajowego Rejestru Długów, Upadłość konsumencka a dostęp do kredytu, listopad 2008 r., s. 19.

57 P. Bodył-Szymala, Ogłosiłeś upadłość konsumencka, zapomnij o weselu, Rzeczpospolita z dnia 20.06.2009, nr 143, s. c7. 
rience. But was it a step in good direction? Maybe new provisions will serve as a vehicle for debtors to escape their creditors or they create only an illusion of second chance. There is a lot of question marks but for reply we have to wait.

Keywords: consumer bankruptcy, consumer law, civil law 